\title{
食品微生物研究の推進をめざす 一日本食品微生物学会の発足・発展をふりかえる一
}

\author{
寺山武 \\ (東京都予防医学協会)
}

\section{Promoting Food Microbiology Researches \\ - Retrospects of Inauguration and Development of Japanese Society of Food Microbiology-}

\author{
Takeshi TERAyAmA \\ (Tokyo Association of Health Service, 1-2 Sadohara-cho, \\ Ichigaya, Shinjuku-ku, Tokyo 162-8402)
}

Key words: 食品衛生微生物研究会, 日本食品微生物学会, 学会の発足・発展経過

はじめに

食物は人の生命維持に不可欠なあのであり, 人類が生 存する限り食物とのかかわりを断っことはできない，食 物は人を含め, 動物の生命維持・成長・繁殖に必須な栄 養を保持するばかりでなく, 食物に含まれる栄養素は微 生物, 特に細菌之真菌にとって, かっこうな培養基質で あるから, 食物と微生物とのかかわりは人類永遠の検討 課題といえよう。

食物と微生物とのかかわりを人類側の立場でみると, 大きく 3 つのカテゴリーに分類することができる.

その 1 つは, 人類にとって有効に作用するもので, 発 酵と呼ばれる現象により各種の副生成物を産出し, それ が人に有効に活用されるケースである。

その 2 は, 人類にとって不利に㗢く作用で, その 1 つ は腐敗・変敗と呼ばれる現象で, 食物としての利用価値 の低下・傊にかかわるケースである.

第 3 は，人類に危害を与える作用にかかわるもの，す なわち, 食中毒や伝染病, さらに微生物の副生成物の長 期摄取による慢性疾患等にかかわるケースである.

食品微生物研究は, こうしたそれぞれの分野にかかわ る多くの研究者により遂行され，それらの成果はそれぞ れの研究者の所属するいろいろな学会や研究会で発表さ れ, 討議されてきた. さらに, 食物の由来別に, 水産物 に関する微生物学的課題は水産学会で, 酪農製品にかか わるものは酪農学会, 畜産学会, 獣医学会などでという ように, 食品微生物にかかわる研究成果はいろいろな分 野で発表・討議されてきた。

画162-8402 東京都新宿区市谷砂土原町 1-2

\section{日本食品衛生学会の設立とその背景}

日本に扔ける食品微生物研究の推進・発展を顧みると き, 日本食品衛生学会の果たした役割を見逃すことはで きない。

日本食品衛生学会は「食品の改善と食品衛生の向上を はかることは, 科学諸分野の衆知を集めて研究すべき問 題である」という主旨により, 医学, 薬学, 農学, 水産 学など各部門にわたって連絡をとり, 昭和 35 年 10 月 に創立された。

本学会は, 厚生省食品衛生調查会委員の有志を中心と して企画されたことが記されている.

食品衛生に加加る化学的問題屯微生物学的問題屯, 食物にかかわる衛生上の問題として一元的に研究・発展 させる必要があるという観点から, 公衆衛生学の分野よ り, 分離・独立した学会である ${ }^{1 !}$.

日本食品衛生学会の発起人名簿には, 厚生省, 国立研 究機関, 医学・薬学・農学・水産学系大学, 主だった医 薬・食品関連企業や主婦連関係などの 80 人の著名人の 名前がっらなっている.

学会発足当初より, 学会の組織は確固たるものとされ ており, 理事 40 名 (内, 会長 1 名, 副会長 2 名, 常任理 事 10 名), 幹事 3 名, 評議委員 29 名, 顧問 13 名 (衆議 院議員 1 名, 参議院議員 2 名を含む), 編集委員 15 名, 賛助会員 30 社, これらが編成され, 学会規約む第 1 章 ～第 7 章にわたる 39 条から成る立派な規約が整備され ていた.

日本食品衛生学会の創立に当たっての準備委員会の討 議段階では, 「食品化学会」とする構想ああったが, 食品 
衛生を通じて社会に貢献するには, 広く食品関連学会を 包含して食品衛生学会とする方がよいという説が有力で あったために，その方向に踏み切ったという，初代日本 食品衛生学会会長の食品衛生学雑誌の「創刊号の発行に あたって」の挨拶の中に記されている21.

しかしながら, 本学会の活動は全体的にみれば化学分 野に関する研究が主流であり, 微生物分野の研究発表は やや影の薄い存在であることはいなめない状況であっ た.

昭和 30 年には粉乳を原因食とする大規模なブドウ球 菌食中毒事件が発生し,さらに, 昭和 30 年代には「いわ ゆる病原性好塩菌」と呼ばれていた腸炎ビブリオ食中毒 の実態が把握されるに及び, 地方衛生研究所等を中心之 して, 細菌性食中毒に関する研究が飛躍的に推進される ようになった。そうした研究発表は日本公衆衛生学会, 日本食品衛生学会, 日本感染症学会, 日本細菌学会, 日 本獣医公衆衛生学会等, 各種の学会において盛んに行わ れるようになった。

国際的には Food Microbiology という概念が定着し ており, 米国微生物学会 (ASM) では, 学会の一分野とし て, Food Microbiology というセクションが設けられ, そこで食品微生物に関する研究成果が発表され, 盛んに 討議されているような状況であった。

我が国においても，食品に関する微生物学的諸問題を 集中して研究・推進・討議する場を期待する声がささや かれていたが, 具体的にそれを企画推進する動きはみら れず, やや寂しさはあるあのの, 食品微生物研究の推進 役は長い間日本食品衛生学会が負っていたといえよう. そうした意味で, 食品微生物研究の推進役として, 日本 食品衛生学会の果たした役目は大きかったといえよう.

\section{食品衛生微生物研究会の発足}

食品微生物研究をより一層推進しようとする理想をか かげ, 発足したのが日本食品微生物学会の前進である食 品衛生微生物研究会である. 食品衛生微生物研究会の発 足は昭和 55 年 6 月である.

日本食品衛生学会が創立されてからちょうど 20 年後 のことである. 食品衛生微生物研究会の発足は日本食品 衛生学会の創立とまったく趣を異にし, 実際に陣頭に 立って食品衛生微生物研究に携わってきた研究者を中心 に計画され，行政領域，研究領域と民間で食品の品質管 理等に関与する領域の, 官, 学, 民の 3 分野において, 食品の微生物学的問題に取り組んでいる多くの方々に働 きかけ，会員を募集して結成されたものである.

本研究会の当初の事業は年 1 回学術講演会を開催す ることであり, 第 1 回の学術講演会はその年の 11 月 13・14 日の 2 日間にわたり, 東京で開催された。第 1 回学術講演会の世話人は倉田浩博士 (国立衛生試験所 衛生微生物部長 当時) である. 昭和 55 年 6 月 2 日を 発足日として,「“食品衛生微生物研究会” 発足趣意書」
を各分野の方々に配布して, 研究会への参加を呼びか け，5力月後の 11 月に学術講演会を開催するという短 い準備期間にもかかわらず, 学術講演会当日の入会者を 含めると, 一般会員 475 名, 賛助会員 45 社という大い なる反響であった。一般会員の構成は地方衛生研究所関 係 159 名, 大学・短大・尃門学校関係 64 名, 行政関係 106 名, 民間企業関係 106 名, 国立研究機関関係 17 名, 不明 23 名というように, 官, 学, 民を結集した研究会に しようとした当初の目論見を具現した会員構成となっ た.

昭和 55 年 6 月 2 日付で個人や企業に発送された “食 品衛生微生物研究会” 発足趣意書は, これまでに学術講 演会講演要旨集やその後に発行された研究会の機関誌 “食品と微生物” の研究会記録にも, 記録として保存され ていないので, ここに, その全文を掲載する.

\section{“食品衛生微生物研究会” 発足趣意書}

先生には益々御清祥のこととお慶び申し上げます.

この度, 同封の会則による「食品衛生微生物研究会」 を発足させる運びとなりました，申し上げるまでむな く, 最近の我が国における生活環境の変化は著しく, ま た科学技術の飛躍的進歩に伴って生産される食品むます ます多様化しつつあります，それらの食品の生産から消 費までの各過程における衛生管理の問題はもちろん, 品 質管理の面において微生物学的問題に限っても, 今後さ らに多角的に検討する必要があると存じます。

食品衛生微生物研究会は, 食品の安全性や品質管理に 加わる微生物学的研究を担当される各専門分野の研究 者が一堂に会して十分に討議し, 互いの知識, 技術の情 報交換を密にして一層の研究の発展を期するため発足し た次第であります.

これらの分野に携わる多くの方々の御参加をお願いす ベく御案内申し上げます.

昭和 55 年 6 月 2 日 食品衛生微生物研究会

発起人

$$
\text { 発起人一同 }
$$

\begin{tabular}{|c|c|}
\hline 浅川 豊 & （静岡県衛生 \\
\hline 加藤 博 & (千葉大学) \\
\hline 川端俊治 & （国立予防衛生研究所） \\
\hline 倉田 浩 & （国立衛生試験所） \\
\hline 口玄二 & （大阪府立大学） \\
\hline 牛千三 & （都立衛生研究所） \\
\hline 笹島正秋 & （東海区水産研究所） \\
\hline 清水 潮 & （東京大学海洋研究所） \\
\hline 鈴木 昭 & （国立衛生試験所） \\
\hline 堀江 進 & （東京水産大学） \\
\hline 文雄 & （実践女子大学） \\
\hline 上 & （都立衛生研究所） \\
\hline 部昭宣 & （埼玉県衛生研究所） \\
\hline
\end{tabular}

（五十音順） 
食品衛生微生物研究会第 1 回学術講演会に際して開 催された総会において, 本研究会の発足経過が報告さ れ，その概要は講演要旨集 ${ }^{3)}$ と 1984 年に発行された研 究会の機関誌である食品と微生物, 第 1 巻, 第 1 号に記 載されている4). しかし，会員の世代交代とともに，食品 衛生微生物研究会の発足経過の実状を知る会員が少なく なりつつあり，具体的な経過についても記録にとどめる ことは意義あると思われるので，以下にその全文を記 す.

\section{食品衛生微生物研究会・発足経過報告（全文）}

食品衛生微生物研究会結成に際して, 尽力された都立 衛生研究所の坂井千三先生が本研究会発足までの経過を ご報告する予定でありましたが，先生には最近健康を害 しまして，本日ここにご出席いただけませんでしたの で, 先生に代わって, 私から経過をご報告させていただ きます。

ご承知のように, 食品に関する微生物学的問題は非常 に広範な分野にわたっておりますので, 各分野で研究さ れている先生方は, その所属されている学会, 例えば, 日本食品衛生学会, 日本公衆衛生学会, 日本獣医公衆衛 生学会, 日本水産学会, 日本細菌学会等で研究成果を発 表し, 討議されております。こうした種々の分野で食品 の微生物学的問題を研究されております諸先生方が一堂 に会して, 多角的に食品の微生物学的諸問題を考え, 検 討することは意義あることと考えられます．坂井先生 は，こうした考えのあとに，機会あるごとに多くの先生 方にその必要性をアピールされておられました.

その考えに同調された先生方は大変に多く，それらの 先生方を中心として食品衛生微生物研究会の結成が検討 されてきたあのであります.

そして，その具体的な動きとして，昭和 54 年 10 月 9 日に, 研究会発足のための第 1 回準備会が, 坂井先生の お世話のもとに，都立衛生研究所で開かれました。準備 会のメンバーは発起人名簿に記されている, 浅川, 加藤, 川端, 倉田, 阪口, 坂井, 清水, 鈴木, 宮沢, 村上, 堀 江の各先生方であります.

まず，この準備会では，研究会の名称，目的，会則， 事業等が検討されました。 そして, 研究会の名称を食品 衛生微生物研究会とすることが決定されました。

第 2 回準備会は昭和 55 年 1 月 25 日に開かれたが, この会は直ちに発起人会とすることが合意されました.

発起人としては, 第 1 回準備会のメンバーに笹島と渡辺 の両先生に加わっていただくことになりました.

この会を第 1 回発起人会として, この会で会則の大要 が決定されるとともに, 食品衛生微生物研究会の暫定役 員が決定され, 暫定役員会のもとで, 本研究会の発足に 全力で当たることになりました。

暫定役員として, 会長に阪口玄二, 副会長に浅川 豊, 総務幹事に坂井千三，庶務幹事に寺山 武, 会計幹事に 一言 広, 集会幹事に鈴木 昭, 編集幹事に村上 一の
各先生が決定されました.

第 1 回暫定役員会が昭和 55 年 3 月 5 日に開催され, 会員の募集, 研究会の発足趣意書の作成, 総会ならびに 学術講演会の開催, 研究会の顧問の推薦等が検討され, その原案が作成されました。

昭和 55 年 4 月 24 日に暫定役員および発起人の合同 会がもたれ, 先の暫定役員会で作成された事項が審議さ れ, 承認されました. そしてさっそく食品衛生微生物研 究会の発足のための具体的作業が暫定役員会のもとで進 められることになりました。

記念すべき食品衛生微生物研究会の第 1 回学術講演 会は坂井先生ととあに, 本研究会の発足に尽力された倉 田 浩先生（国立衛生試験所）に世話人となっていただ き開催されることになった．倉田先生のご努力により， ここに,このように盛大な発足総会を兼ねた学術講演会 が開催されることになったのであります.

先ほど, 食品衛生微生物研究会の会員の現況報告にも あったように, 非常に大勢の先生方および本研究会をご 理解賜り, 多数の賛助会員の参加を迎ぐことができまし たのは, 食品衛生微生物研究会の機能の重要性を示すむ のと思われます. 今後, 皆様方のご協力により, 本研究 会が発展することを切望いたし, 簡単ではありますが本 研究会発足までの経過報告といたします（昭和 55 年 11 月 13 日, 食品衛生微生物研究会・発足総会における本 研究会発足経過報告, 庶務幹事).

以上が食品衛生微生物研究会の発足経過であるが, そ の後, 本研究会は回を重ねるごとにさらに多くの参加者 を迎え，発展し続けることになった。

本研究会発足 4 年後の昭和 59 年には, 本研究会の機 関誌である「食品と微生物」第 1 巻第 1 号が刊行され た.

食品衛生微生物研究会の機関誌「食品之微生物」は, 発刊当初は年間 2 号であった。 その内容は，1号では主 に学術講演会で発表された特別講演, 教育講演やシンポ ジウム等に関する全容が， 2 号には食品微生物に関する 原著論文が掲載された。

平成 2 年に日本食品微生物学会に改組されるまでの 第 1 巻〜第 6 巻までは, こうした編集方針で雑誌が刊行 されてきた。

本研究会の学術講演会は, 毎年 1 回, 関東地区と関西 地区で交互に開催しょうと申し合わされ，2 年続いて一 方に偏ったこともあるが，第 9 回まではおおむねそのよ うに開催されてきた. 第 10 回学術講演会は初めて広島 市で開催されることになり，参加者の集まりが危惧され ていたが，実際に開催してみるとその危惧がまったく無 用で, 世話人をはじめ役員一同をほっとさせるほど，極 めて盛会であった.

\section{食品微生物学会への改組}

食品衛生微生物研究会の実質的発案者である坂井先生 
（都衛生研究所）は，本研究会の設立を計画した時点にお いて，将来は学会に発展させようという構想をむっての ぞまれていた．食品衛生微生物研究会の構成会員の推移 をみると, 発足後 $4 \sim 8$ 年経過した時点で, 出入りの激 しい短期的会員が 200 300 名程度みられるものの, 継 続的会員が 600 名程度を維持していたこと，また食品衛 生微生物研究会の学術講演会に参加された会員に, 研究 会から学会への改組について意見を求めたところ，ほと んどの会員が賛成されていたので，役員会としても意を 強くし，学会への改組を本格的に検討することになっ た.

食品衛生微生物研究会の役員の任期は 2 年であった から，第 5 期の役員の任期は，本研究会発足後ちょうど 10 年となり，これを節目として学会へと発展させるこ とは大变意味深いものがあると考えられた。よって，第 5 期の役員会 (寺山会長, 加藤副会長) のもとで学会へ の改組を具体的に検討し, 食品衛生微生物研究会は発足 後 10 年にして発展的に解消することにした。

学会への改組のため, 役員会の中に将来計画委員会を 設置することになり，役員の中からその委員として阪 口, 橋本, 仲西, 一言, 渡辺の各先生が任命された。こ の委員会で学会の名称, 定款, 学会への移行の具体的な 手順等が検討された。

学会の名称は, 単に食品の衛生にかかわる微生物学的 問題だけでなく，微生物の有効利用などに関する課題を も包含する, 広い視野にたって, 食品の微生物学的問題 を検討する学会にしようとする意図をむって，食品微生 物学会とすることが決定された。そして，学会の機関誌 である「食品と微生物」の名前はそのままにするが，そ の下に食品微生物学会雑誌と補足することになった。

食品微生物学会に改組されたのを機に，学会雑誌を年 間 4 号発行することが検討され，とりあえず第 7 巻は 3 号とし, 第 8 巻以降は 4 号の発行がなされるようになっ た.

\section{学会の名称・学会機関誌の名称変更}

科学分野における日本のほとんどの学会の名称には頭 に日本が付されており, 学会の機関誌には当然のことな がら頭に日本が付されて, 日本○○学会雑誌という名称 になっている.

日本の付されていない食品微生物学会の機関誌である
「食品と微生物」に掲載された論文は，公的機関におい て, 商業雑誌に投稿されたあのとみなされやすく，学術 的価值が低く評価されることが懸念されるとの意見が提 示された。

食品衛生微生物研究会の機関誌として,「食品と微生 物」が刊行された時点で, この雑誌の英文名は Japanese Journal of Food Microbiology となっていたので，英 文名は変更することなく，和文名だけを変更すればすむ ことなので，学会名および雑誌の和文名を变更すること が理事会, 評議委員会および会務総会で提案され，それ が了承された.

学会名は平成 6 年度加ら日本食品微生物学会に変更 され, 雑誌名は第 10 巻を区切りとして, 第 11 巻より日 本食品微生物学会雑誌に名称が变更されることになっ た。また，公文書サイズの国際化に伴い，用紙サイズを B5 判加ら A4 判に変更し, 紙面もより充実したものと することが編集委員会より提案され，それが了承され て, 現在の日本食品微生物学会雑誌が刊行されるように なった。

ちなみに, 平成 10 年 1 月 20 日現在, 日本食品微生物 学会の一般会員は 1,053 名, 名誉会員 15 名, 賛助会員 106 社，購読会員 $72 ，$ となっている.

おわりに

日本に打ける食品微生物に関する専門的学会として, 日本食品微生物学会が学問的に, また, 社会的にも一応 の評価を受けるようになったことは，本学会の前進であ る食品衛生微生物研究会の発足の時点から関係した者の 一人として，誠に喜ばしい限りである。発足 15 年にし て，一応学会の基礎は築かれたと考えられる。我が国に おける, これからの食品微生物研究の推進役として, 日 本食品微生物学会の果たす役割は大きいと思われる. 本 学会のさらなる発展を期待するしだいである.

\section{参考資料}

1）日本食品衛生学会編集委員会：食衛誌，1, 118 (1960).

2）刚米達夫：食衛誌. 1, 1 (1960).

3) 食品衛生微生物研究会: 食品衛生微生物研究会- 第 2 回 学術講演会講演要旨集, 57 (1961).

4) 食品衛生微生物研究会 事務局: 食品と微生物, 1, 7 (1984). 